\title{
ZONASI BAHAYA KEGEMPAAN AKIBAT PATAHAN AKTIF DI WILAYAH JAWA TIMUR DENGAN PENDEKATAN DETERMINISTIK MENGGUNAKAN PERHITUNGAN ATENUASI CHIOU-YOUNGS 2014 NGA
}

\section{Augustika Ratna Salsabil, Anik Hilyah, Singgih Purwanto, dan M Haris Miftakhul Fajar}

Departemen Teknik Geofisika, Fakultas Teknik Sipil, Lingkungan dan Kebumian, Insitut Teknologi Sepuluh Nopember

e-mail: augustikaratnas@gmail.com

\begin{abstract}
Abstrak. Studi mengenai bahaya kegempaan dilakukan untuk meminimalisasi dampak dari bencana gempa bumi di wilayah rawan bencana gempa. Penelitian ini mempresentasikan analisis bahaya kegempaan dalam bentuk nilai Peak Ground Acceleration (PGA) dengan menggunakan pendekatan deterministik untuk wilayah Jawa Timur. Metode ini membuat simulasi sumber gempa patahan sehingga mendapatkan nilai PGA yang dihitung dari fungsi atenuasi terpublikasi yaitu Chio-Youngs 2014 NGA. Selanjutnya digunakan data Vs30 USGS sebagai batasan kedalaman lapisan batuan daerah penelitian. Rentang nilai PGA yang dihasilkan berkisar antara $0,0099 \mathrm{~g} \mathrm{~m} / \mathrm{s}^{2}$ untuk nilai terendah hingga 2,0014 m/ $\mathrm{s}^{2}$ untuk nilai tertinggi. Hasil analisa menunjukkan nilai PGA tinggi berada pada daerah dengan Vs30 rendah, dimana pada daerah tersebut memiliki rentang Vs30 rendah berkisar antara $180 \mathrm{~m} / \mathrm{s}$ hingga $332,62 \mathrm{~m} / \mathrm{s}$. Kondisi geologi didominasi oleh sedimen alluvium meliputi kerakal, kerikil, batupasir, batulempung, lanau dan konglomerat. Wilayah ini merupakan zona rawan gempa bumi dikarenakan kondisi geologi yang memicu terjadinya amplifikasi gelombang gempa. Secara keseluruhan, daerah rawan mengalami kerusakan akibat gempa meliputi Kabupaten Bojonegoro, Kabupaten Nganjuk, Kabupaten Lamongan, Kabupaten Gresik, Kabupaten Jombang, Kabupaten Mojokerto, Kota Surabaya, Kabupaten Sidoarjo, Kabupaten Pasuruan dan Kabupaten Probolinggo.
\end{abstract}

Kata Kunci: PGA; gempa; patahan; deterministik

\begin{abstract}
The study of seismic hazards was carried out to minimize the impact of earthquake disasters in earthquake prone areas. This study presented seismic hazard analysis in the form of Peak Ground Acceleration (PGA) values using a deterministic approach for the East Java region. This method makes a fault source earthquake simulation so that the PGA value is calculated from the published attenuation function of Chio-Youngs 2014 NGA. Furthermore USGS Vs30 data is used as a limitation of the depth of the rock layer in the study area. The range of PGA values produced ranged from $0.0099 \mathrm{~g} \mathrm{~m} / \mathrm{s} 2$ for the lowest value up to $2.0014 \mathrm{~m} / \mathrm{s} 2$ for the highest value. The results of the analysis showed that the high $P G A$ values were in areas with low Vs30, where the area has a low Vs30 range ranging from $180 \mathrm{~m} / \mathrm{s}$ to $332.62 \mathrm{~m} / \mathrm{s}$. Geological conditions dominated by alluvium sediments include glacial, gravel, sandstone, claystone, silt and conglomerates. This region is an earthquake-prone zone due to geological conditions that trigger the amplification of earthquake waves. Overall, areas prone to earthquake damage include Bojonegoro, Nganjuk, Lamongan, Gresik, Jombang, Mojokerto, Surabaya, Sidoarjo, Pasuruan and Probolinggo.
\end{abstract}

Keywords: PGA; earthquake; fault; deterministic

\section{PENDAHULUAN}

Jawa Timur adalah salah satu provinsi di Pulau Jawa yang akan merasakan dampak ketika terjadi gempabumi. Selain dari zona subduksi, gempa dangkal bersumber di daratan juga sering terjadi di Jawa dalam beberapa puluh tahun terakhir. Padatnya permukiman di Jawa, gempa-gempa ini menimbulkan dampak yang cukup merusak, misalnya gempa bumi Gandasuli (1982),
Majalengka (1990), Bumi ayu (1994), dan Yogyakarta (2005) (Soehaimi, 2008).

Hasil pemutakhiran peta gempa 2017 oleh Pusat Gempa Nasional (Pusgen), di jawa timur terdapat sesar yang tergolong aktif, yaitu sesar kendeng (terdiri dari sesar cepu, blambangan, waru dan surabaya), sesar pasuruan, sesar probolinggo dan sesar wonorejo (Koulali dkk., 2017; Lestari dkk., 2018; Marliyani, 2015; Rochman dkk., 2018).

Mitigasi bencana gempabumi sangat diperlukan 
untuk mengurangi bahaya yang diakibatkan oleh kejadian gempabumi. Salah satu metodenya menggunakan analisis seismic hazard(Kumala, 2016). Analisis bahaya kegempaan yang digunakan pendekatan deterministik dengan atenuasi chiou youngs 2014, dikarenakan digunakan sumber gempa dangkal patahan aktif darat jawa timur (Chiou dan Youngs, 2014). Analisis bahaya tersebut direpresentasikan dalam bentuk peak ground acceleration (PGA) atau gerakan tanah maksimum yang terjadi di suatu tempat saat mengenai suatu getaran.

\section{DASAR TEORI}

\section{Geologi Regional Daerah Penelitian}

Daerah penelitian berada di wilayah administrasi Jawa Timur. Secara fisiografis, Jawa Timur di bagi menjadi tujuh satuan. Satuan tersebut dari selatan menuju utara adalah pegunungan selatan, busur vulkanik kuarter, zona pusat depresi Jawa, zona Kendeng, zona depresi Randublatung, zona Rembang-Madura dan dataran aluviat uatara Jawa. Berikut adalah gambaran fisiografi Jawa bagian Timur oleh Van bemmelen (1949).

Secara umum, struktur geologi Jawa Timur didominasi oleh Alluvium dan bentukan hasil gunung api kwarter muda. Dimana usia rata-rata pengendapannya relatif muda yaitu miosen hingga holosen. Hal ini menyebabkan batuan belum terkonsolidasi dengan baik dibandingkan dengan batuan sedimen yang memiliki usia lebih tua.

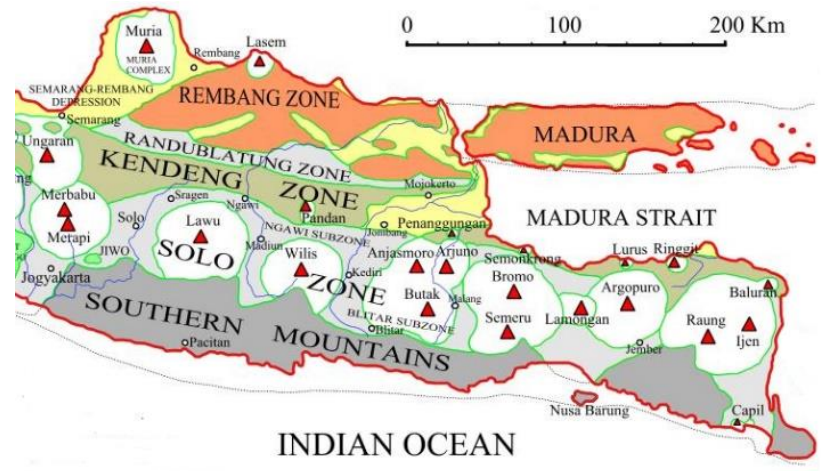

Gambar 1. Peta fisiografi Jawa bagian Timur (Bemmelen, 1949)

\section{Gempa}

Gempa bumi sebuah istilah dimana terjadi suatu getaran di permukaan bumi yang disebabkan olehi pergerakan mendadak pada suatu tubuh batuan karena proses pelepasan dari akumulasi regangan (strain) energi di luar batas elastis batuan. Kebanyakan gempa bumi disebabkan dari suatu tegangan pada lempengan yang bergerak kemudian melepaskan energi. Semakin lama tegangan itu semakin membesar dan akhirnya mencapai pada keadaan di mana tegangan tersebut tidak dapat ditahan lagi oleh massa batuan. Besar kekuatan gempabumi biasanya diukur dengan menggunakan 3 skala, yaitu:

a. Berdasarkan energi yang dilepaskan di pusat gempa

Biasanya disebut dengan Magnitudo atau Skalla Richter. Magnitudo menunjukkan besaran atau jumlah energi yang dilepaskan pada suatu pusat gempa (Hypocenter) yang dapat diukur dengan seismograf. Magnitudo pertama kali didefinisikan oleh Charles Richter tahun 1935, sehingga kini dikenal sebagai Skala Richter. Gempa dengan skala 3 magnitudo atau lebih biasanya hampir tidak terlihat, dan gempa dengan skala magnitudo 7 biasanya lebih berpotensi menyebabkan kerusakan serius di daerah yang luas, tergantung pada kedalaman gempa. Gempa bumi terbesar bersejarah besarnya telah lebih dari 9, meskipun tidak ada batasan besarnya (Natawidjaja dan Triyoso, 2007).

b. Berdasarkan tingkat kerusakan yang diakibatkan oleh gempa

Biasanya disebut dengan Intensity (intensitas), digunakan dalam menentukan kuatnya getaran tanah akibat suatu gempa dengan melihat respon orang atau bangunan yang terasa atau terjadi pada saat gempa berlangsung pada lokasi tertentu. Intensitas gempa dikenalkan oleh boen yahun 2002 kemudian dinyatakan secara sederhana, merupakan derajat kerusakan akibat gempa bumi atau intensitas maksimum yang dihasilkan oleh gempa tersebut. Umumnya menggunakan skala intensitas menurut tingkat kerusakan atau yang dirasakan manusia. Salah satu skala intensitas yang dikenal adalah MMI (Modified Mercalli Intensity) digunakan sejak tahun 1956.

c. Berdasarkan Percepatan batuan dasar maksimum

Data PGA merupakan data gempa yang diperlukan untuk kepentingan design bangunan. Untuk 
mengetahui besarnya PGA, bisa dihitung dari besarnyamagnitudo dan kedalaman gempa, kemudian dengan rumus atenuasi yang kinisudah berkembang hingga beberapa generasi (Natawidjaja dan Triyoso, 2007). Gerakan tanah yang terjadi pada lapisan bawah tanah atau batuan padat, karakteristiknya dijelaskan menggunakan parameter amplitudo yaitu percepatan tanah maksimum, kecepatan tanah maksimum dan pergeseran maksimum. PGAdinyatakan dalam satuan percepatan gravitasi (Gravitational Acceleration $=$ gal) atau $\mathrm{cm} / \mathrm{s} 2$. Nilai percepatan tanah maksimum yang dihasilkan menunjukkan tingkat resiko bencana yang terjadi. Dua metode untuk menentukan nilai PGA, yaitu melalui pengukuran alat (accelerograf) dan perhitungan empiris. Pendekatan metode empiris tidak selalu benar, namun cukup memberikan gambaran umum tentang percepatan tanah maksimum

\section{Metode Deterministic Seismic Hazard Assessment (DSHA)}

metode deterministik, dilakukan pembentukan skenario gempa tertentu di batuan dasar dengan memperhitungkan gempa yang terjadi pada suatu lokasi tertentu dalam besaran gempa tertentu. Skenario gempabumi ini berisi mengenai kejadian gempabumi dengan magnitudo tertentu yang akan terjadi pada lokasi tertentu. Metode ini mudah digunakan untuk memprediksi gerakan tanah (ground motion) akibat dari gempabumi, namun metode ini tidak mempertimbangkan pengaruh dari ketidakpastian terkait dalam analisis. Pada metode DSHA, biasanya mengikutsertakan keputusan serta pendapat subyektif dari para ahli, khususnya dalam penentuan potensi gempa. Akibatnya dalam hal ini terdapat kesulitan dalam pencapaian kesepakatan mengenai potensi gempa yang terjadi (Bambang Sunardi, 2016; Kumala, 2016).

Output dari sebuah analisis bahaya kegempaan dapat bermacam-macam. Salah satunya adalah peak ground acceleration. PGA dapat diartikan sebagai percepatan gempa (ground velocity) dapat dihitung sebagai percepatan di batuan dasar (ground acceleration) maupun percepatan gempa dipermukaan tanah. Nilai PGA dapat dihitung dengan mempergunakan fungsi antenuasi. Fungsi atenuasi adalah suatu fungsi yang menggambarkan korelasi antara intensitas gerakan tanah setempat (a), Magnitude Gempa (M), serta jarak dari suatu titik dalam daerah sumber gempa ( $r$ ). Para ahli telah banyak merumuskan fungsi atenuasi dimana fungsi atenuasi yang berlaku di suatu tempat belum tentu berlaku di tempat yang lain, karena fungsi atenuasi sangat tergantung pada kondisi alam di suatu tempat. Pemilihan fungsi atenuasi didasarkan pada kesamaan kondisi geologi dan tektonik dari wilayah dimana fungsi atenuasi tersebut dikembangkan (Irsyam dkk, 2016).

\section{Fungsi Atenuasi Chiou-Youngs 2014 NGA}

Fungsi atenuasi merupakan persamaan matematika sederhana yang menghubungkan antara parameter kegempaan di lokasi pusat gempa (Magnitudo $M$ dan jarak $R$ ) dengan parameter pergerakan tanah (spektra percepatan) pada lokasi yang ditinjau. Fungsi atenuasi adalah suatu fungsi khas yang diturunkan dari data gempa pada suatu daerah tertentu. Salah satu data yang

digunakan untuk menurunkan fungsi atenuasi adalah data time history yang diperoleh dari hasil pencatatan alat accelerograph saat kejadian. Penurunan semua model atenuasi didasarkan atas analisis statistik dan gerakan tanah terekam. Di Indonesia, karena minimnya data pencatatan time history, pemakaian fungsi atenuasi yang diturunkan di negara lain tidak dapat dihindari. Penentuan fungsi atenuasi didasarkan pada persamaan kondisi geologi dan tektonik dari wilayah di mana fungsi atenuasi tersebut dibuat (Bambang Sunardi, 2016).

Persamaan Persamaan GMPE Chiou-Youngs (2014) NGA merupakan pengembangan dari ChiouYoungs, 2008. Persamaan ini merupakan hasil pengolahan dari data pencatatan gempa pada tahun 2008 ditambah dengan data pencatatan sampai tahun 2013. Jumlah data yang digunakan untuk pengembangan persamaan ini diperoleh dari lebih dari 20000 data dari 243 peristiwa gempa yang terjadi di California, Jepang, New Zealand, Taiwan dan Turkey dengan magnitude antara 3.1 sampai $\mathrm{Mw}=7,6$. Bentuk umum dari persamaan Chiou-Youngs 2014 NGA dapat dilihat pada Persamaan di bawah:

$$
\begin{aligned}
& \ln (\text { yrefij })=C 1+\left\{C 1 a+\frac{C 1 c}{\cosh (2 \max (M i-4.5,0))}\right\} F r v+ \\
& \left\{C 1 b+\frac{C 1 d}{\cosh (2 \max (M i-4.5,0))}\right\} F n m i+\{C 7+ \\
& \left.\frac{C 1 b}{\cosh (2 \max (M i-4.5,00))}\right\} \Delta Z \text { tori }+\{C 11+ \\
& \left.\frac{C 11 b}{\cosh (2 \max (M i-4.5,0))}\right\}(\cos \delta i)^{2}+C 2 \ln (\text { Rrupij }+ \\
& C 5 \cosh (C 6 . \max (M 1-C h m, 0)))+(C 4 a+
\end{aligned}
$$


C4) $\ln \left(\sqrt{R^{2} \text { rupij }+C r b^{2}}\right)++\{C y 1+$

$\left.\frac{C y 2}{\cosh (\max (M i-C y 3,0))}\right\} \cdot$ Rrupij $+C 8 \max (1-$

$\left.\frac{\max (\text { Rrupij-40,0) }}{30}\right) \min \left(\frac{\max (M i-5.5,0)}{0.8}, 1\right) e^{C 8 a(M i-C 8 b)} \Delta D P P i j+$

C9. FMwij. $\cos \delta i\left\{C 9 a+(1-C 9 a) \tanh \left(\frac{\text { Rrupij }}{2}\right)\right\}\{1-$

$\left.\frac{\sqrt{\text { Rjbij }^{2}+Z t o r i^{2}}}{\text { Rrupij+1 }_{1}}\right\} \ln (Y i j)=\ln ($ Yrefij $)+$

$\emptyset 1 . \min \left(\ln \left(\frac{V s 30 j}{1130}\right), 0\right)+$

$\varnothing 2 .\left\{e^{\varnothing 3(\min (V s 30 I J, 1130)-360)}-\right.$

$\left.e^{\emptyset 3(1130-360)}\right\} \cdot \ln \left(\frac{\text { Yrefij } e^{n i}+\emptyset 4}{\emptyset 4}\right)+\emptyset 5 \cdot\{1-$

$\left.e^{\left(\frac{\Delta Z}{\varnothing 6}\right)}\right\}+n 1$

Keterangan :

M :Moment Magnitude

RRUP : jarak terdekat ke bidang rupture $(\mathrm{km})$

RJB : jarak Joiner-Boore $(\mathrm{km})$

$\mathrm{RX} \quad$ : koordinat site $(\mathrm{Km})$ tegaklurus terhadap trace fault

FHW : Hanging Wall flag; 1 untuk $\mathrm{RX}>0$ dan 0 untuk $\mathrm{RX}<0$

$\delta \quad$ : sudut dip rupture

Ztor : kedalaman puncak rupture $(\mathrm{km})$

Frv : 1 untuk 3001500 dan FRV = 0 untuk yang

lain (reverse danreverse-oblique)

Fnm : 1 untuk-1200 -600 dan FNM = 0 untuk yang lain (normal dannormal-oblique)

Vs30 : kecepatan geser rata-rata untuk kedalaman tanah $30 \mathrm{~m}$ paling atas(m/dtk)

Z1.0 : kedalaman dengan nilai kecepatan rambat gelombang geser $1 \mathrm{Km} / \mathrm{s}$

$\Delta$ Z1.0 : nilai rata-rata Z1.0 untuk model spesifik California

DPP : direct point parameter untuk directivity effect

$\triangle \mathrm{DPP}$ : nilai rata-rata DPP (Chiou dan Youngs, 2014).

\section{METODOLOGI PENELITIAN}

\section{Parameter sumber gempa data Vs30}

Data yang digunakan hanya patahan aktif di wilayah Jawa Timur dan diperoleh dari data terbaru Pusat Studi Gempa Nasional (PUSGEN) tahun 2017.
Terdapat 7 segmen patahan aktif yaitu patahan pasuruan, patahan wonorejo, patahan probolinggo, patahan surabaya, patahan waru, patahan blumbang serta patahan cepu. Masing-masing patahan memiliki parameter yang berbeda-beda sebagai berikut:

\begin{tabular}{|c|c|c|c|c|c|}
\hline Segmen & Tipe & Strike & Dip & $\begin{array}{l}\text { Panjan } \\
\text { g (km) }\end{array}$ & Magnitudo \\
\hline $\begin{array}{l}\text { Patahan } \\
\text { Cepu }\end{array}$ & $\mathrm{R}$ & ESE & $45 S$ & 100 & 6.5 \\
\hline $\begin{array}{l}\text { Patahan } \\
\text { Waru }\end{array}$ & $\mathrm{R}$ & EW & $45 S$ & 64 & 6.5 \\
\hline $\begin{array}{l}\text { Patahan } \\
\text { Surabaya }\end{array}$ & $\mathrm{R}$ & ESE & $45 S$ & 25 & 6.5 \\
\hline $\begin{array}{l}\text { Patahan } \\
\text { Blumbang }\end{array}$ & $\mathrm{R}$ & NE & $45 S$ & 31 & 6.6 \\
\hline $\begin{array}{l}\text { Patahan } \\
\text { Pasuruan }\end{array}$ & $\mathrm{N}$ & none & $60 \mathrm{~S}$ & 18 & 6.5 \\
\hline $\begin{array}{l}\text { Patahan } \\
\text { Probolinggo }\end{array}$ & SS & none & $60 N$ & 15 & 6.5 \\
\hline $\begin{array}{l}\text { Patahan } \\
\text { wonorejo }\end{array}$ & $\mathrm{N}$ & none & $60 \mathrm{E}$ & 10 & 5.7 \\
\hline
\end{tabular}

Lokasi patahan aktif tersebut tersebar dari ujung timur hingga barat Jawa Timur dan mendominasi wilayah bagian utara. Berikut adalah peta Jawa Timur beserta lokasi patahan aktif

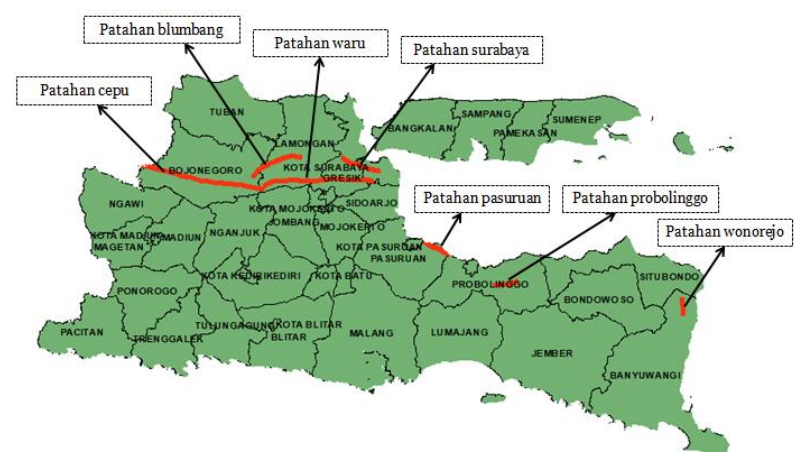

Gambar 2. Lokasi Patahan

Data VS30 yang digunakan dalam penelitian ini adalah data sekunder yang diperoleh dari United State Geological Survey (USGS). Format data dari USGS adalah .tif. Untuk mendapatkan nilai VS30 maka dilakukan ekstrak nilai menggunakan software ArcMap 3.1. USGS telah melakukan pendugaan nilai Vs30 dengan parameter kemiringan lereng yang diperoleh melalui citra satelit. Kemiringan lereng mencerminkan kekerasan 
batuan dan ketebalan sedimen, sifat fisik batuan yang menentukan kecepatan gelombang permukaan. Berikut adalah hasil pemetaan nilai Vs30 Jawa Timur.

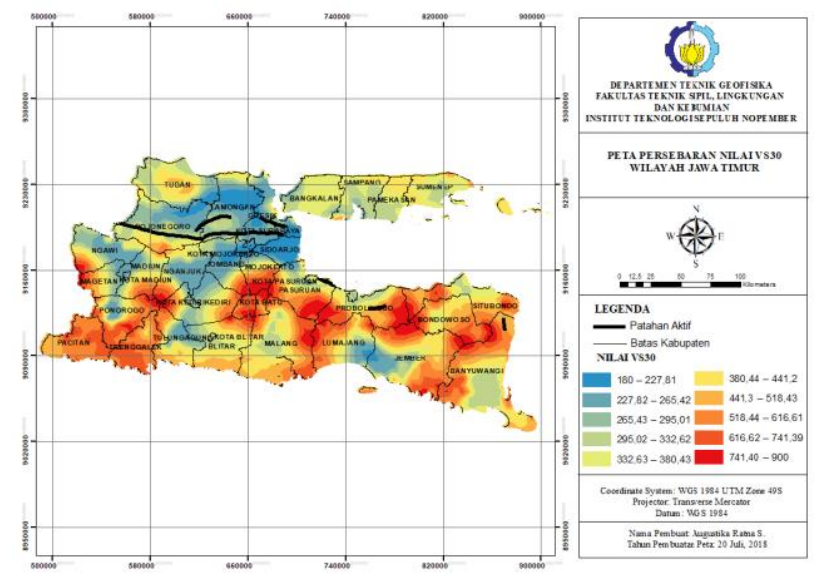

Gambar 3. Peta pesebaran nilai VS30 wilayah Jawa Tmur

Nilai Vs30 Jawa Timur memiliki rentang terendah $180 \mathrm{~m} / \mathrm{s}$ hingga tertinggi sebesar $900 \mathrm{~m} / \mathrm{s}$. Dapat dilihat untuk nilai Vs rendah lebih banyak pada daerah utara Jawa Timur. Tepatnya pada sekitar Kabupaten/Kota Sidoarjo, Kota Surabaya, Kabupaten Gresik, Kabupaten Lamongan, sebagian Kabupaten Mojokerto ,Kabupaten Jombang, Kabupaten Bojonegoro, Kabupaten Nganjuk dan sebagian Kabupaten Tuban. Kabupaten tersebut di atas memiliki rentang nilai Vs30 rendah sebesar $180 \mathrm{~m} / \mathrm{s}$ hingga 295,011 m/s. Dengan rentang nilai sekian, maka berdasarkan klasifikasi tanah NEHRP nilai tersebut masuk dalam kelas $E$ yaitu soft soil profile dan kelas $D$ yaitu stiff soil profile. Klasifikasi tersebut sesuai dengan batuan yang terdapat di daerah-daerah tersebut. Antara lain dari lempung, lanau, pasir, kerikil, kerakal, bongkahan maupun tanah urukan.

Kemudian nilai paling tinggi yang ditandai dengan warna merah, mendominasi pada daerah gunung dan pegunungan. Hal ini dapat dilihat dari pola melingkar merah di bagian tengah Jawa Timur hingga menuju selatan Jawa Timur. Adapun gunung yang terdapat di bagian tengah tersebut antara lain Gunung Lawu (dari bagian barat) daerah Magetan, kemudian gunung Kawi, Gunung Arjuno, Gunung Semeru, Gunung bromo hingga paling Timur terdapat pegunungan ljen. Serta daerah kapur pada sekitar Kota Pacitan yang ditandai dengan skala $441,19 \mathrm{~m} / \mathrm{s}$ hingga $741,39 \mathrm{~m} / \mathrm{s}$. Sedangkan unutk wilayah Madura, nilai Vs30 pada skala menengan yaitu dari $265,41 \mathrm{~m} / \mathrm{s}$ hingga $441,19 \mathrm{~m} / \mathrm{s}$. Tidak terdapat topografi yang signifikan pada daerah tersebut, juga tidak terdapat endapat aluvial atau sedimen tebal. Berikut adalah pesebaran nilai Vs30 di wilayah administrasi Jawa Timur

Daerah pegunungan memiliki nilai Vs30 lebih tinggi adalah karena adanya pengaruh elevasi atau ketinggian yang berhubungan erat dengan kekerasan batuan. Pada puncak bukit seperti gunung maupun pegunungan, pelapukan terjadi secara intensif dan memiliki tingkat lebih tinggi. Sedangkan sedimentasi atau pengendapan berada pada tingkat yang lebih rendah. Sebaliknya terjadi pada daerah cekungan, pelapukan berada pada tingkat lebih paling rendah dibandingkan dengan sedimentasi. Secara lebih sederhana dapat dikatakan bahwa batuan yang berada di puncak bukit seperti gunung maupun pegunungan merupakan batuan yang keras dan tahan terhadap pelapukan. Maka gunung dan bukit khususnya yang berumur tersier dapat dikatakan sebagai sumber material untuk sedimentasi. Sedangkan cekungan yang berada di daerah yang lebih rendah merupakan endapan muda yang lunak.

Selain itu, faktor kemiringan lereng (slope) dapat mengindikasikan ketebalan lapisan sedimen. Material hasil pelapukan akan diendapkan lebih tebal pada bagian yang mempunyai kemiringan lereng lebih kecil. Material sedimen di lereng akan jauh lebih tipis dibandingan dengan endapan sedimen dalam suatu cekungan. Jarak titik pengendapan terhadap sumber material sedimen berperan penting dalam besar butir sedimen yang diendapkan. Makin jauh jarak titik dari sumber akan makin halus material sedimen yang diendapkan, demikian juga sebaliknya. Seperti halnya pada pasir pantai, butiran-butiran tanahnya sangat halus dibandingkan pada daerah pegunungan yang masih terdapat butiran dengan ukuran kerikil. Besar butir sedimen berpengaruh terhadap kekerasan batuan sedimen, makin halus material sedimen, makin lunak endapan sedimen.

\section{Titik pengamatan}

Lokasi penelitian berada di wilayah Jawa Timur. Secara geografis terletak pada koordinat $111,0^{\circ}$ Bujur Timur hingga $114,4^{0}$ Bujur Timur dan garis 
lintang $7,12^{\circ}$ Lintang Selatan dan $8,48^{\circ}$ Lintang Selatan. Dengan luasan tersebut, maka dibuat suatu titik pengamatan dimana interval antar titik sejauh $5 \mathrm{~km}$ dengan jumlah total sebanyak 1923 titik. Karena dalam membuat suatu zonasi daerah berbahaya diperlukan data yang memiliki keakuratan baik. Semakin rapat titik pengamatan atau grid yang dibuat, maka semakin rapat data yang diperoleh. Dalam kasus ini, Jarak tersebut mewakili radius daerah yang akan diamati. Sehingga nilai peak ground acceleration yang dihasilkanakan akan tersebar sesuai grid yang tersedia.

\section{Pembobotan nilai PGA}

Pada dasarnya, setiap sumber gempa yang pada penelitian ini adalah patahan aktif, memiliki dampak yang berbeda dalam menimbulkan suatu gerakan tanah. Hal ini dikarenakan parameter yang terdapat dari masing-maisng patahan juga berbeda. Maka pertama dilakukan perhitungan nilai PGA terlebih dahulu pada masing-masing patahan. Kemudian dibobotkan dari semua patahan menjadi satu sumber gempa. Hasilnya akan diperoleh suatu nilai PGA atau gerakan tanah yang merepresentasikan sebuah bahaya kegempaan yang diakibatkan oleh patahan aktif di Jawa Timur. Besarnya pembobotan didasarkan dari besarnya potensi magnitudo dari masing-maisng patahan. Berikut adalah sekma pembobotan penelitian:

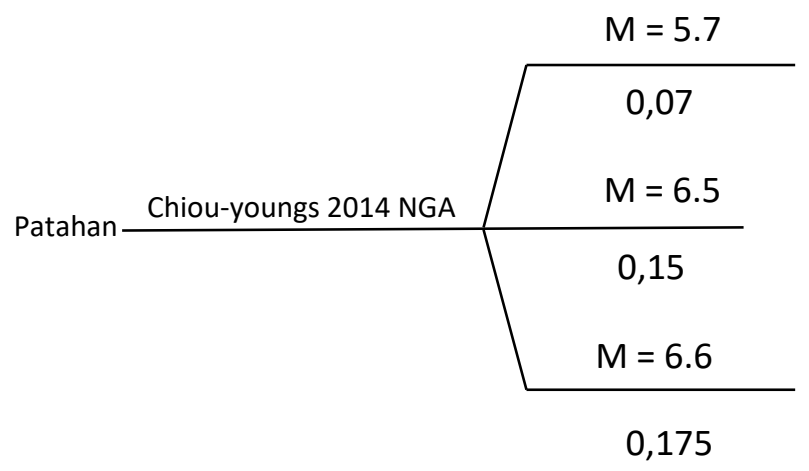

Gambar 4. Pembobotan penelitian

\section{Grafik spectral accelertion}

Akselerasi spektrum (SA) adalah satuan yang diukur dalam g (percepatan karena gravitasi bumi, setara dengan g-force) yang menggambarkan percepatan maksimum dalam gempa bumi pada objek. Kemudian nilai SA ini divisualisasikan kedalam bentuk grafik. Fungsi dari grafik ini antara lain dapat melihat perkiraan nilai maksimum pada periode tertentu serta melihat perilaku akselerasi spektra pada suatu skenario gempa di periode tertentu.

Berikut adalah respon spektrra akselerasi dari perhitungan fungsi atenuasi dalam bentuk grafik hubungan periode dengan percepatan spectra. Masing-masing grafik tersebut kemudian digabungkan agar terlihat perbandingan responnya. Respon di bawah ini diambil dari satu studi kasus sumber gempa yaitu pada patahan Cepu. Kemudian di ambil sampel pada dua titik pengamatan yang berbeda. Satu berada pada daerah yang memiliki nilai Vs30 tinggi yaitu $846,598 \mathrm{~m} / \mathrm{s}$. Satu lainnya di ambil pada daerah dengan Vs30 rendah dengan nilai $201,47 \mathrm{~m} / \mathrm{s}$. Titilk pengamatan tersebut juga mempertimbangkan jarak terhadap sumber patahan yang juga tidak jauh berbeda. Berikut adalah grafik responnya:
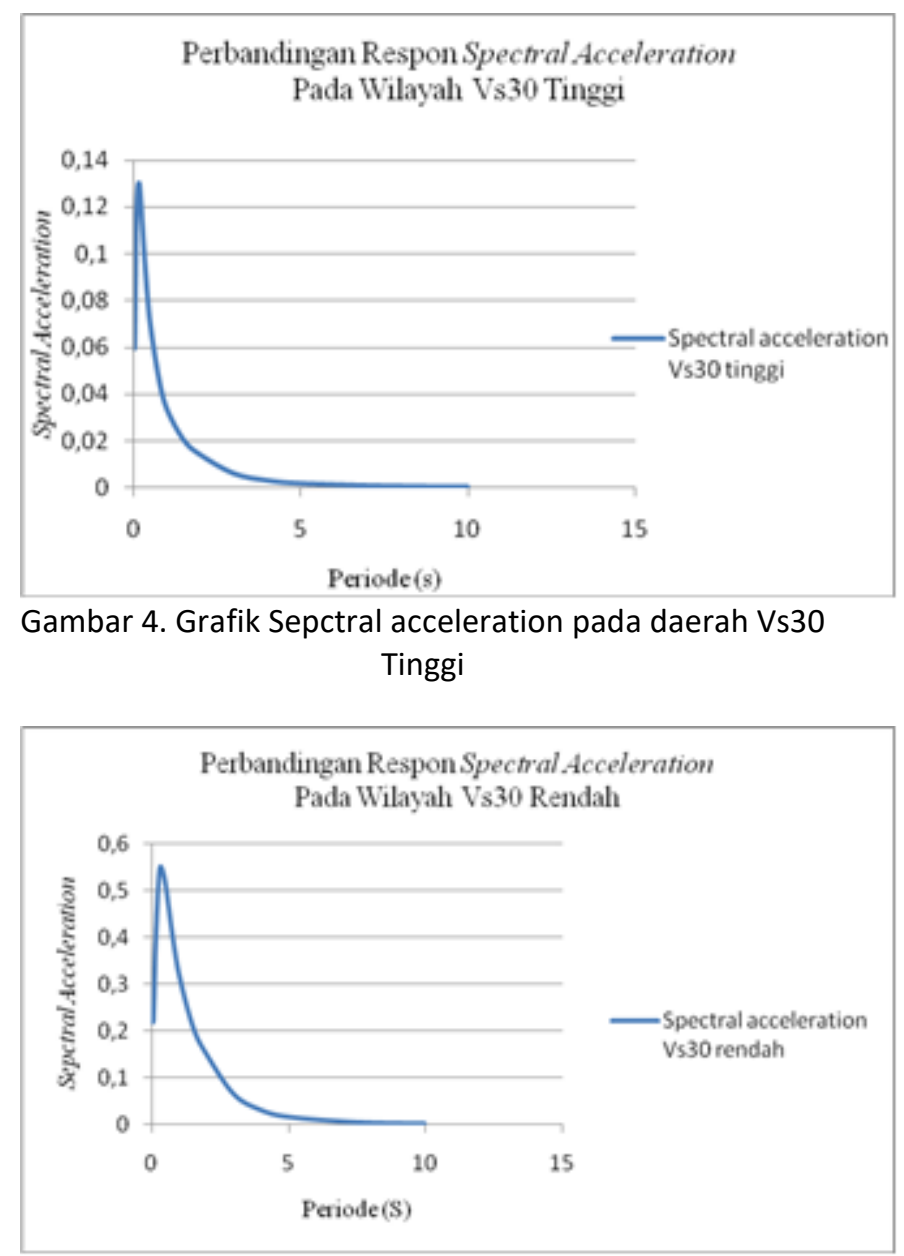

Gambar 5. Grafik Sepctral acceleration pada daerah Vs30 Rendah

Periode antara respon pada daerah dengan nilai 
Vs30 tinggi dan rendah adalah sama. Perbedaan terdapat pada rentang nilai percepatan spektranya. Daerah dengan nilai Vs30 tinggi memiliki nilai percepatan yang jauh lebih rendah. Dengan rentang nilai $0,02 \mathrm{~m} / \mathrm{s}^{2}$ hingga puncaknya tidak sampai $0,14 \mathrm{~m} / \mathrm{s}^{2}$. Nilai yang dihasilkan pada penelitian ini adalah $0,00042497 \mathrm{~m} / \mathrm{s}^{2}$ hingga $0,13018 \mathrm{~m} / \mathrm{s}^{2}$. Daerah dengan nilai Vs30 rendah memiliki nilai percepatan yang jauh lebih tinggi. Dengan rentang nilai $0,1 \mathrm{~m} / \mathrm{s}^{2}$ hingga puncaknya tidak sampai $0,6 \mathrm{~m} / \mathrm{s}^{2}$. Nilai yang dihasilkan pada penelitian ini adalah $0,0025423 \mathrm{~m} / \mathrm{s}^{2}$ hingga 0,5507 $\mathrm{m} / \mathrm{s}^{2}$.

\section{Zonasi Daerah Rawan Bahaya}

Pada penelitian ini, sumber yang digunakan adalah patahan aktif yang berada pada zona administrasi wilayah Jawa Timur. Jumlah sumber gempa sebanyak tujuh buah dengan variasi potensi maginitudo serta panjang patahan yang berbeda. Setelah dilakukan perhitungan numerik, kemudian diperoleh nilai puncak percepatan tanah maksimum atau dikenal sebagai Peak Ground Acceleration (PGA). Acceleration pada istilah ini bisa dirasakan sebagai perubahan dari kecepatan dalam suatu waktu. Sedangkan nilai terbesar dari beberapa perubahan kecepatan dalam satuan waktu tersebut dikenal sebagai nilai Peak. Maka PGA dapat diartikan sebagai akselerasi maksimum yang dirasakan suatu partikel/lapisan ketika terjadi gerakan gempa. Nilai dari PGA cenderung digunakan untuk memprediksi kekuatan suatu bangunan saat terkena gelombang gempa. Maka dari itu, fokus kedalaman pada penelitian ini terbatas hingga 30 meter. Angka ini diperoleh dari analisis lapisan sedimen rata-rata di Wilayah Jawa Timur dan rekomendasi beberapa referensi yang menyatakan bahwa perencaanaan pembangunan yang membutuhkan data nilai gelombang geser hingga kedalaman 30 meter (Vs30). Berikut adalah hasil pemetaan zona bahaya gempa akibat patahan aktif di Jawa Timur.

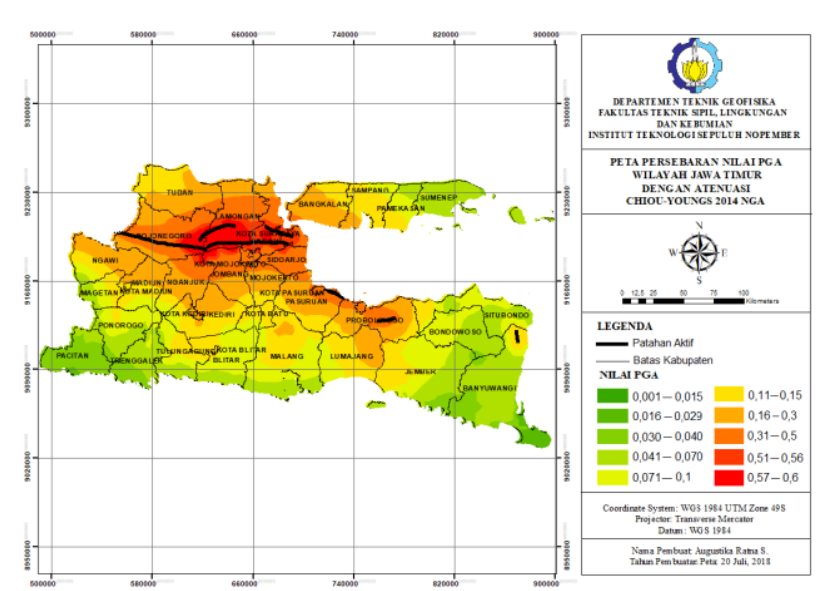

Gambar 5. Peta bahaya gempa dengan sumber patahan aktif darat Jawa Timur

Gambar di atas memperlihatkan adanya akumulasi nilai PGA tinggi terjadi pada utara Jawa Timur. Jika ditinjau dari rentang nilai Vs30, rentangnya tergolong rendah hingga menengah yaitu berkisar $180 \mathrm{~m} / \mathrm{s}$ hingga 518,43 m/s. Namun di dominasi oleh nilai rendah dengan rentang 180 $\mathrm{m} / \mathrm{s}$ hingga $295,010 \mathrm{~m} / \mathrm{s}$. Nilai ini dapat di validasi dengan kondisi sebenarnya pada daerah tersebut yakni tersusun oleh dominasi sedimen berupa aluvium. Antara lain dari lempung, lanau, pasir, kerikil, kerakal, bongkahan maupun tanah urukan. Namun juga terdapat barisan struktur karst di pantai utara Jawa Timur seperti di Kabupaten Lamongan dan Kabupaten Gresik. Selain itu, 4 dari 7 patahan berada pada daerah tersebut, 2 lainnya berada di kisaran Kabupaten Pasuruan dan Probolinggo serta satu lainnya di ujung timur Jawa Timur. Maka dari itu energi terakumulasi pada daerah tersebut. Rentang nilai PGA yang dihasilkan berkisar antara 0,0099 g untuk nilai terendah dan nilai tertinggi sebesar $2,0014 \mathrm{~g}$. Sebagai upaya validasi maka digunakan peta sumber dan bahaya gempa Indonesia yang telah dipublikasi oleh pusat studi gempa nasional. Secara umum bentukan pesebaran nilai PGA relatif sama. Terdapat pebedaan dalam ketelitian pesebaran akibat skala peta pusgen yang terlalu luas. Rentang nilai PGA dari peta pusgen untuk wilayah Jawa Timur berkisar antara kurang dari 0,05 g hingga 0,7 g. Nilai ini relatif tidak jauh berbeda dengan hasil akhir pembobotan PGA pada penelitian.

Secara umum, terlihat daerah rawan dengan nilai PGA tinggi pada daerah dekat sumber gempa yaitu wilayah Surabaya hingga Madura bagian barat dekat dengan selat madura-Surabaya. Kemudian 
untuk nilai PGA rendah dengan warna hijau adalah di daerah Bayuwangi, dimana daerah cukup jauh dengan sumber gempa serta daerah Pacitan.Meskipun daerah pacitan tidak sejauh Banyuwangi, namun kondisi geologi di daerah tersebut merupakan karst dan batuan beku dikarenakan terdapat pegununan kapur. Menurut peta geologi Jawa Timur, daerah pacitan sekitarnya didominasi oleh batuan Gunung Api Oligo-Miosen. Dimana tersusun perselingan breksi gunung api, lava dan tuf, bersisipan batupasir, batulanau dan batulempung tufan. Bersusunan andesit-basal, terpropilitkan, terlipat dan terkekar sangat kuat. Serta batu gamping miosen awal-tengah yaitu batu gamping hablur, kalkarenit bagian bawah, sisipan batu lempung berkarbonat atau tufan dan sedikit gampingan.Sebagian terpualamkan dan terpiritkan akibat pengaruh terobosan andesit sehabis magmatik.Pada daerah Magetan juga amplifikasi terlihat teredam daripada di sekitarnya dikarenakan terdapat gunung Lawu yang memiliki struktur geologi kompak dari batuan beku.Jadi nilai Vs30 pada daerah tersebut juga tinggi. Sehingga amplifikasi dapat teredam pada batuan kompak daripada daerah sedimen lunak seperti wilayah pesisir pantai tuban, lamongan, pasuruan, probolinggo serta daerah dengan endapan vulkanik muda sekitar pegunungan tengah Jawa Timur seperti pada daerah bojonegoro.

Kemudian jika ditinjau lebih lanjut, terdapat pola melingkar dengan skala warna yang menunjukkan nilai PGA rendah pada beberapa daerah Jawa Timur bagian tengah. Dimana daerah tersebut terdapat beberapa gunung aktif seperti Gunung Semeru, Gunung Kawi, Gunung Arjuno, Gunung Welirang dan lain sebagainya. Serta terdapat anomali nilai PGA yang cenderung lebih tinggi dengan pola melingkar pada daerah banyuwangi (Jawa timur bagian timur-selatan). Hal ini dianalisis adanya daerah dengan susunan batuan sedimen oligo-miosen dengan perselingan batu pasir batu lanau, batu lempung dan konglomerat aneka bahan serta beberapa batugamping dari laut dangkal. Sedimen inilah yang menyebabkan peningkatan amplifikasi, nilai PGA lebih tinggi dan gelombang akibat gempa lebih dirasakan.

\section{PENUTUP}

\section{Simpulan dan Saran}

Dari hasil penelitian Analisis Bahaya Kegempaan di Jawa Timur dengan penggunakan pendekatan deterministik dapat disimpulkan bahwa nilai PGA (Peak Ground Acceleration) untuk Wilayah Jawa Timur berkisar antara 0,0099 g untuk nilai terendah dan 2,0014 g untuk nilai tertinggi. Daerah dengan nilai PGA tertinggi meliputi Kabupaten Sidoarjo, Kota Surabaya, Kabupaten Lamongan dan Kabupaten Gresik. Dimana pada daerah tersebut memiliki rentang Vs30 rendah berkisar antara $180 \mathrm{~m} / \mathrm{s}$ hingga 332,62 m/s. Kondisi geologi didominasi oleh sedimen alluvium meliputi kerakal, kerikil, batupasir, batulempung, lanau dan konglomerat. Sedangkan Daerah dengan nilai PGA terendah Kabupaten Pacitan, Kabupaten Trenggalek, Kabupaten Banyuwangi dan Kabupaten Sumenep, Madura. Dimana pada daerah tersebut memiliki rentang Vs30 tinggi berkisar antara 518,43 $\mathrm{m} / \mathrm{s}$ hingga $900 \mathrm{~m} / \mathrm{s}$. Kondisi geologi didominasi oleh batuan gunung api miosen yaitu basal, andesit, perselingan breksi, sisipan batupasir, batulempung serta batugamping. Hasil analisa menunjukkan bahwa nilai PGA tinggi berada pada daerah dengan Vs30 rendah. Wilayah ini merupakan zona rawan gempa bumi dikarenakan kondisi geologi yang memicu terjadinya amplifikasi gelombang gempa.

\section{DAFTAR PUSTAKA}

Bambang Sunardi, S.S.M.C. and G.A. (2016), Deagregasi bahaya gempabumi untuk daerah istimewa yogyakarta, No.November 2015.

Bemmelen, R.W. van (1949), The geology of Indonesia, Govt. Printing Office, The Hague.

Chiou, B.S.-J. dan Youngs, R.R. (2014), "Update of the Chiou and Youngs NGA Model for the Average Horizontal Component of Peak Ground Motion and Response Spectra", Earthquake Spectra, Vol.30, No.3, hal. 1117-1153. http://doi.org/10.1193/072813EQS219M.

Koulali, A., McClusky, S., Susilo, S., Leonard, Y., Cummins, P., Tregoning, P., Meilano, I., Efendi, J. dan Wijanarto, A.B. (2017), "The kinematics of crustal deformation in Java from GPS observations: Implications for fault slip partitioning", Earth and Planetary Science Letters, Vol.458, hal. 69-79. 
http://doi.org/10.1016/j.epsl.2016.10.039.

Kumala, S.A. (2016), Analisis Nilai PGA ( Peak Ground Acceleration ) untuk Seluruh Wilayah Kabupaten dan Kota di Jawa Timur, Inersia, Vol.21, No.1 hal. 37-43.

Lestari, W., Widodo, A., Warnana, D.D., Syaifuddin, F., Utama, W. dan Rochman, J.P.G.N. (2018), Mapping of Kendeng Thrust Active Fault in East Java Using Magnetotelluric Method, http://doi.org/10.3997/2214-4609.201800424.

Marliyani, G. (2015), Evidence of Multiple GroundRupturing Earthquakes in the Past 4000 Years along the Pasuruan Fault, East Java, Indonesia, Agu, Diambil dari https://agu.confex.com/agu/fm15/webprogram /Paper79115.html.

Natawidjaja, D.H. dan Triyoso, W. (2007), "the Sumatran Fault Zone - From Source To Hazard", Journal of Earthquake and Tsunami, Vol.01, No.01, hal. 21-47. http://doi.org/10.1142/S1793431107000031.

Rochman, J.P.G.N., Warnana, D.D., Syaifuddin, F., Lestari, W. dan Mahsa, A. (2018), Application of Gravity Method for Local Geological Structures Identification in Surabaya, http://doi.org/10.3997/2214-4609.201800437.

Soehaimi, A. (2008), "Seismotektonik Dan Potensi Kegempaan Wilayah Jawa", Indonesian Journal on Geoscience, Vol.3, No.4, hal. 227-240-240. http://doi.org/10.17014/ijog.3.4.227-240. 
LAMPIRAN

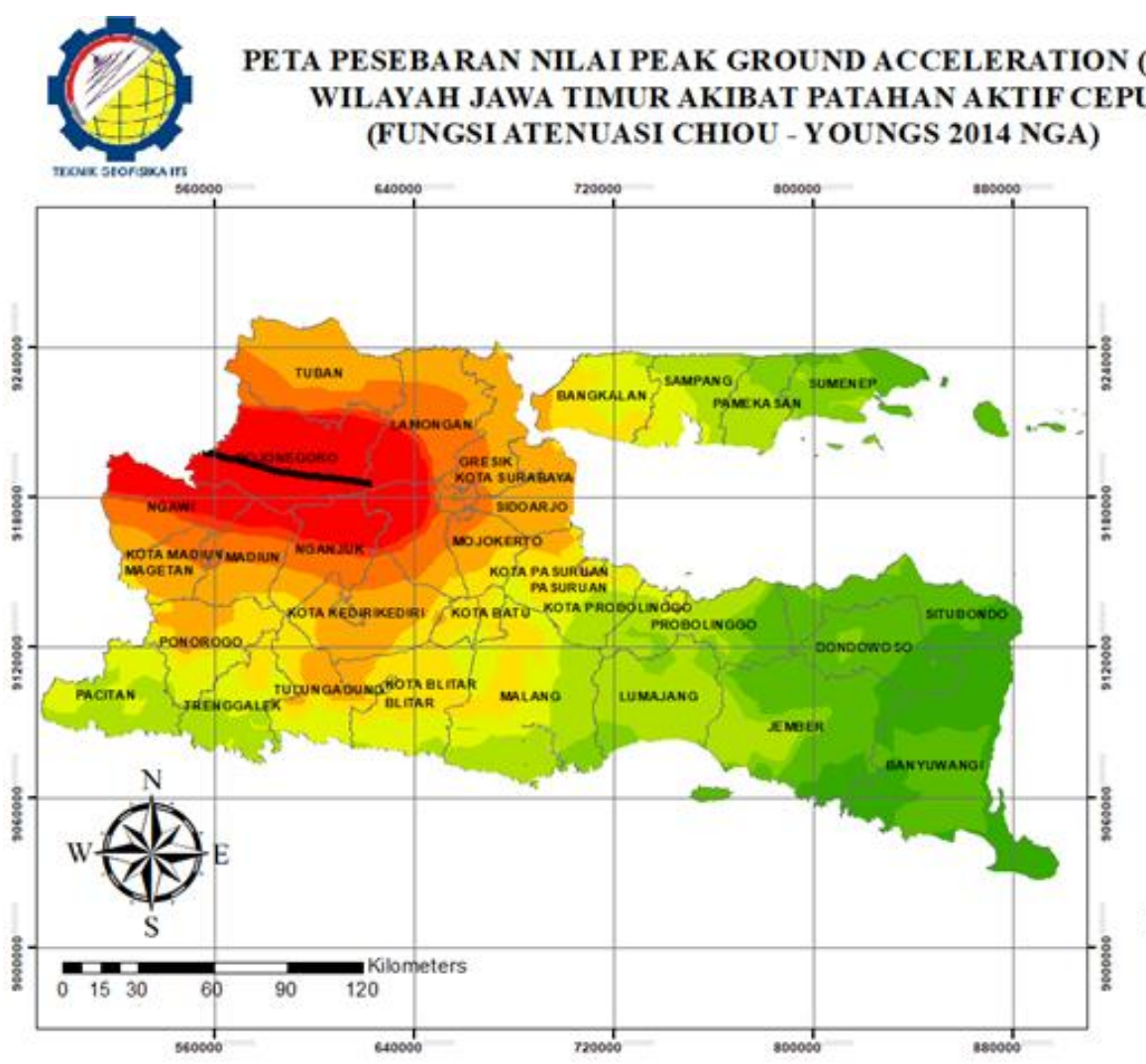

LEGENDA

- Patahan Cepu Batas Kabupaten NILAI PGA

\section{$0.001-0.015$}

$0,016-0,029$

$0,030-0,04$

$0,041-0,07$

$0,071-0,1$

$0,11-0,15$

$0,16-0,3$

$0,31-0,5$

$0,51-0,56$

$0,57-0,6$

Coordinate System WGS 1984 UTM Zone 49 s Datum WGS 1984

Augustika Ratna S DEPARTEMEN TEKNTK GEOISIKA FAKLLTAS TEKVIK SIPLL NSTITUT TEKNOLOGI SEPCLUH NOPEMBER 